\title{
Osmotic Properties of some Plant Cells at Low Temperatures.
}

BY

FRANCIS J. LEWIS, D.Sc., F.R.S.E. \& C., F.L.S.,

AND

GWYNETHE M. TUTTLE, M.Sc.,

Botanical Department, Universiiy of Alberta, Edmonton, Canada.

With five Figures in the Text.

- Contents.

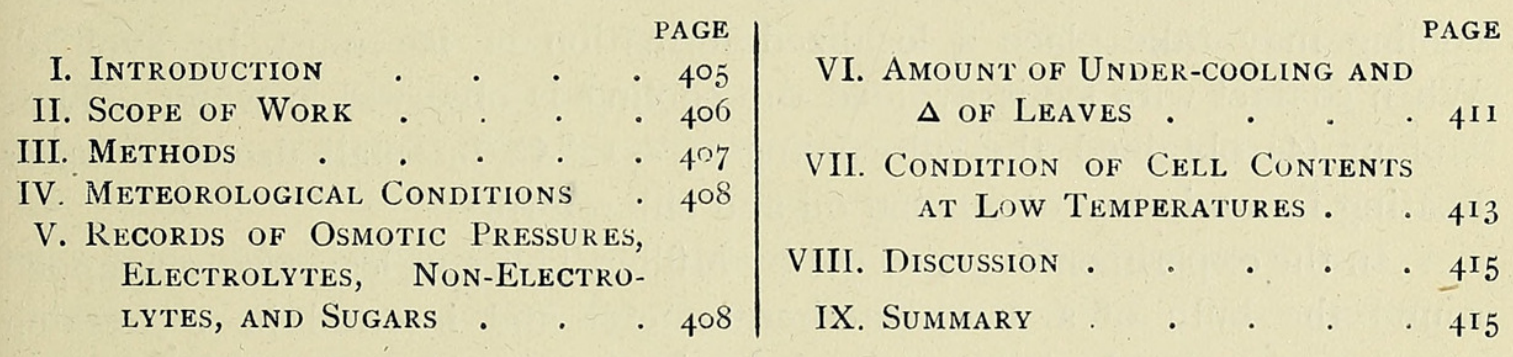

\section{INTRODUCTION.}

URING the last few years the cryoscopic method of determining the osmotic pressure of plant saps has largely replaced the older plasmolytic methods. Investigations have been directed to seasonal changes in the constitution of the sap, as well as to changes due to differences in habitat, both in the same species and in different species characteristic of various plant formations.

The most recent work dealing with the first aspect of the subject is the work published by Dixon and Atkins in the Proc. Royal Dublin Society (5). These authors have carried out a fine series of researches on the seasonal changes in osmotic pressure and the relative proportion of electrolytes and non-electrolytes in the cell sap; both in leaves and in the conducting tissues of stems and roots of various plants. This work was directed particularly to the elucidation of the part played by osmotic pressure in the ascent of sap. Attention was paid to methods of extracting the plant sap to ensure that the extract was a fair sample of the sap within the living cell-a matter to which but little attention had been paid by previous workers.

[Annals of Botany, Vol. XXX1V. No. CXXXV. July, 1920.] 
The ecological side of the problem has been attacked by Harris and Lawrence (1), working on the osmotic pressures of Jamaican rain-forest vegetation. These authors found that vegetation of different ecological habitats possessed different osmotic pressures, but no information is given in their work as to the relative proportion of electrolytes and non-electrolytes in the several types they investigated.

It seems probable that ability to withstand low temperatures depends entirely upon the organization and biochemical characters of the cells. Although attempts have been made to recognize modifications of structure which would enable aerial or subaerial organs to withstand low temperature, none have been found whose presence would render the plant resistant.

An increase in the concentration of the cell sap will lower the freezingpoint, but this seldom amounts to more than $2^{\circ} \mathrm{C}$. Müller (2) has shown that living plants usually have a lower freezing-point than the expressed sap. The fact that the actual freezing-point of the cell is lower is due to surface tension forces, such as capillarity and imbibition. Mousson (3) found that in a capillary tube of not more than $0.4 \mathrm{~mm}$. diameter the freezing-point of water was lowered $0 \cdot 1^{\circ}$ to $0 \cdot 2^{\circ} \mathrm{C}$. In order that subcooling may take place a localized formation of ice must be avoided. When contact with ice is avoided sub-cooling is observed in water. Thus Dufour (4) obtained the sub-cooling of $-12^{\circ} \mathrm{C}$. in small drops of water floating in a mixture of almond oil and chloroform.

In the experiments carried out by Müller-Thurgau, leaves were wrapped round the bulb of a sensitive thermometer and inserted in a freezing mixture with the thermometer scale projecting outside. With this method the temperature sinks until the maximum degree of sub-cooling is reached, and then rises to the true freezing-point, when ice formation takes place, after which it falls gradually. According to Pfeffer the sub-cooling in most plants is not more than $-3^{\circ}$ to $-4^{\circ} \mathrm{C}$. It is important to remember that most previous experiments have been performed with plants living in comparatively temperate climates, and results obtained in this investigation (in Western Canada) with plants subjected to long periods of $-40^{\circ}$ to $-50^{\circ} \mathrm{F}$. have some bearing on the question.

\section{SCOPE OF WORK.}

The scope of the present investigation may be indicated as follows :

I. To determine the osmotic pressure, relative amount of electrolytes and non-electrolytes, and sugars in a few typical plants living at low temperatures from the autumn throughout the winter.

2. To determine the temperature at which ice formation actually takes place in the living cells of the tissues.

3. To observe the condition of the cell contents at low temperature.

The materials chosen for investigation were Picea canadensis (Miller). 
B.S.P., leaves ; Pyrola rotundifolia, L., leaves ; Linnaea borealis, L. var. americana (Forbes), leaves; Populus tremuloides, Michx., cortical tissues. During the winter some difficulty was experienced in collecting Pyrola and Linnaea from under the snow, thus limiting the number of observations that could be made with these plants.

\section{MEthods.}

According to the observation of Dixon and Atkins (5), sap expressed by simple pressure from living tissues does not give a fair sample of the sap in the vacuoles of the living cell. In the researches of these authors the protoplasm of the living cell was rendered permeable to all the solutes by the application of extreme cold, liquid air being used for this purpose. After freezing by this means the protoplasm is killed, rendered quite permeable, and the sap with all the solutes can be extracted by comparatively slight pressure.

As liquid air was not obtainable for these experiments, liquid $\mathrm{CO}_{2}$ was used. This gives a temperature of $-72^{\circ} \mathrm{C}$, which results in the instant freezing of the tissues. The material was then placed in a glass vessel, rapidly thawed, and on treatment in a small screw-press about 25 c.c. of sap could be obtained from a comparatively small amount of material of all the plant tissues investigated. Care was taken to ensure that all the $\mathrm{CO}_{2}$ was evaporated before the extraction of the sap. The increased ease with which the sap is extracted by this method is striking. One sample of untreated cortex of Populus tremuloides gave only a few drops of sap on pressing ; an equivalent weight of cortex killed by freezing yielded I 4 c.c. of sap with slight pressure.

The $\Delta$ of the expressed sap was determined at once-usually within the hour-by the ordinary Beckman method, and the measurement of the electrical conductivity was then measured by the method of Kohlrausch. The estimation of sugars was made by treating the extracted sap with a minimum amount of basic lead acetate to precipitate the tannins. The excess of lead was then removed by sodium carbonate. The extract freed from tannins was tested with Benedict's sodium citrate solution (6). All determinations were made in drops rather than in cubic centimetres, since the quantity of extract available would not permit of the latter method. The same burette was used throughout the investigation, thus ensuring a uniformity in the size of the drops. The results recorded in each case were the number of drops required to decolorize twenty-five drops of Benedict's solution; the relative reducing power of the extract before and after inversion being determined by comparison with that of a standard glucose solution. The relative amount of glucose, sucrose, and maltose were determined according to the methods described by Haas and Hill (7). 
To minimize any marked variation of the sugar content due to variation in photosynthesis at different times of the day, all material was collected at 2 p.m.

\section{Meteorological Conditions.}

Records of the temperature were kept from January onwards by means of a Casella Recording Thermograph. The instrument was fixed on a wall facing north, about sixty feet above the ground. The temperatures recorded were probably slightly above those obtaining at the level of the ground. A reduced record of the maximum and minimum temperature curve is given in Graph I. As the instrument only recorded down to $+10^{\circ} \mathrm{F}$. the breaks in the diagram indicate periods below this temperature. The minima are recorded in figures in these blanks.

The first part of the winter was unusually free from low temperatures, the lowest temperatures coming in February and March.

\section{Records of Osmotic Pressures, \&c.}

All the material was obtained from the same habitat-a slope facing north. Trees of Picea of approximately the same age were used throughout-about fifteen years. To obviate any discrepancy due to individual differences of pressure in the trees, branches were cut from several trees, brought into the laboratory, and the leaves cut off. To eliminate any error due to differences in osmotic pressure of leaves of different ages only those from the previous year's shoot were taken. The leaves were then frozen and thawed in the manner already described and the cell sap expressed. The osmotic pressure was determined immediately, and then the conductivity, the whole process for one observation taking about three hours. The sugar estimation in some cases was made the following day, and in that case the sap remained frozen during the interval.

The depression of the freezing-point and the corresponding pressures in atmospheres are recorded in the tables and in the ordinates of the graphs. The figures in column $\mathrm{C}$ give the conductivity of the sap at $37^{\circ} \mathrm{C}$. The figures under $\Delta_{e}$ are calculated from those under $\Delta$ and $C$, and represent the depression in freezing-point of solutions of potassium chloride having the same conductivity as those observed for the sap. They represent the total $\Delta$ due to electrolytes. The column $\Delta-\Delta_{e}$ represents the total $\Delta$ due to the presence of non-electrolytes in the sap. This method was used by Dixon and Atkins (8), and gives clear indication of the main changes going on in the cell.

The material for the observations on Populus, Limnaea, and Pyrola was obtained from the same habitat as Picea. The respective readings are given in Tables I to IV and recorded in Graphs II to V. The atmospheric 
pressure $\mathrm{P}$ is the value corresponding to the observed $\Delta$ given in the Tables published by Harris and Gortner (9).

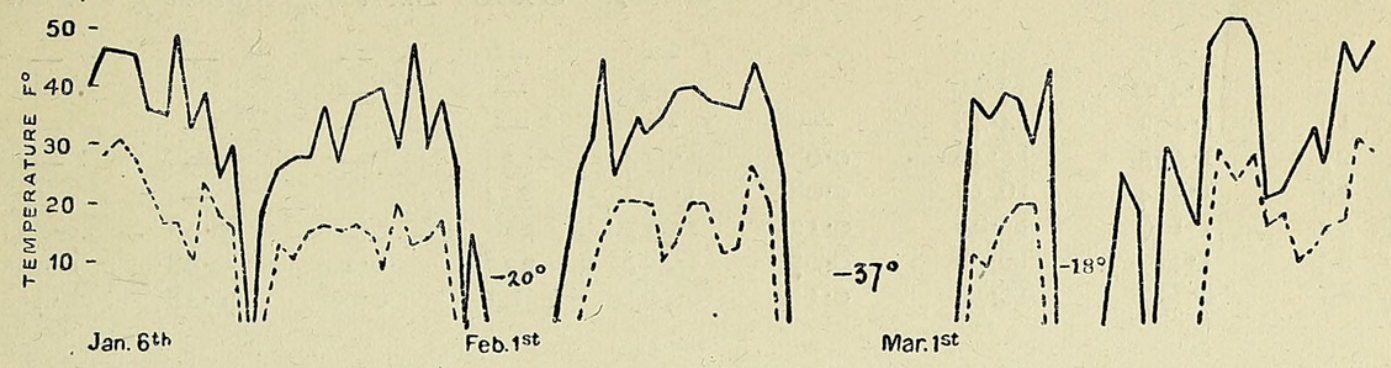

GRAPH I.

Table I. Picea canadensis.

Date. $\quad \Delta . \quad$ P. $\quad \Delta_{e} . \quad \Delta-\Delta_{e} . \quad \mathrm{C} \times 10^{5}$. Sucrose $\%$. Maltose $\%$. Glucose $\%$.

\begin{tabular}{|c|c|c|c|c|c|c|c|c|}
\hline Oct. 23 & $I \cdot 4^{2} 4$ & $17 \cdot 13$ & - & 一 & - & - & - & - \\
\hline Dec. 7 & I.777 & $2 \mathrm{I} \cdot 3^{6}$ & - & - & - & - & - & - \\
\hline , I5 & I. 655 & $19.9 \mathrm{I}$ & - & - & - & - & - & - \\
\hline ", 22 & 1.680 & $20 \cdot 20$ & - & - & - & - & - & - \\
\hline ," 28 & 1.635 & 19.66 & 0.179 & $I \cdot 45^{6}$ & $77^{1}$ & - & - & -- \\
\hline Jan. I & $\mathrm{I} \cdot 5^{86}$ & 19.07 & - & - & - & - & - & - \\
\hline , 8 & $1 \cdot 705$ & 20.50 & 0.187 & $1 \cdot 5^{18}$ & 793 & - & - & \\
\hline, I 8 & $I \cdot 700$ & $20 \cdot 44$ & 0.179 & $\mathrm{I} \cdot 5^{2 \mathrm{I}}$ & 771 & - & - & - \\
\hline Mar. ? & I.909 & 22.94 & 0.214 & 1.695 & $9^{2} \mathrm{I}$ & 0.20 & 0.97 & 0.24 \\
\hline "26 & $2 \cdot 240$ & 26.9 I & 0.143 & 2.097 & 617 & 0.16 & $0.5^{\mathrm{S}}$ & 0.47 \\
\hline April 2 & $1 \cdot 720$ & 20.68 & 0.119 & I.60I & $5^{14}$ & 0.39 & $2 \cdot 00$ & 0.01 \\
\hline & I. 625 & I 9.53 & O. I 42 & $I \cdot 4^{8} 3$ & 612 & 0.62 & 0.00 & I.OO \\
\hline May 26 & $1 \cdot 750$ & $2 \mathrm{I} \cdot 04$ & 0.19 I & $\mathrm{I} \cdot 559$ & 822 & 0.00 & 0.77 & 0.03 \\
\hline June 4 & I.635 & I9.66 & 0.261 & $\mathrm{I} \cdot 374$ & I I 2 I & 0.00 & 0.00 & $I \cdot 00$ \\
\hline
\end{tabular}

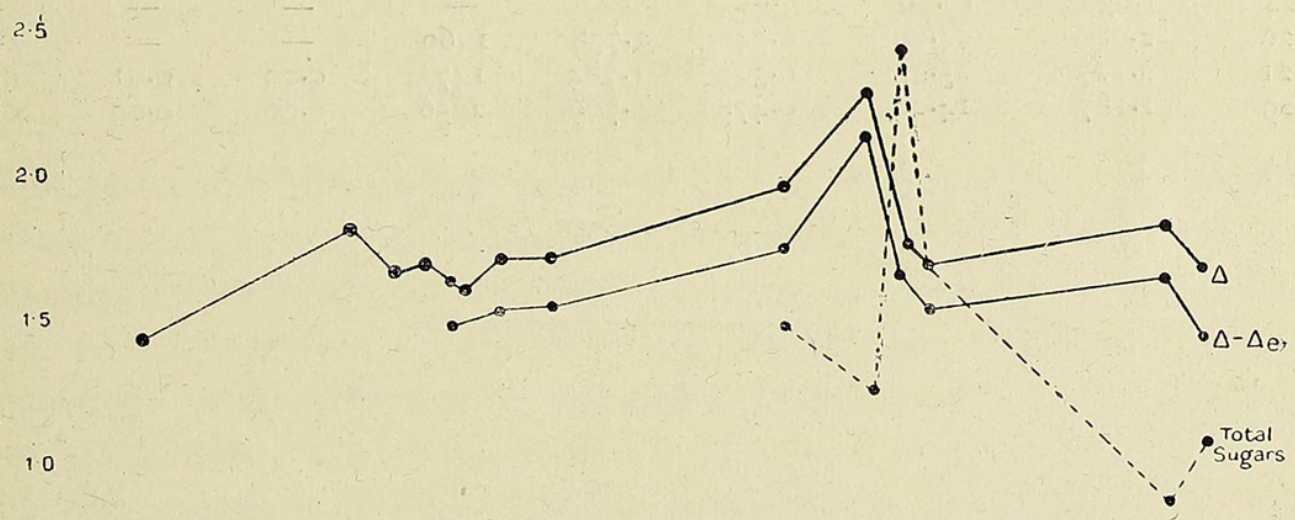

0.5

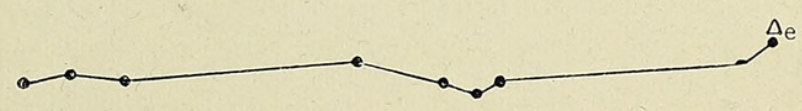

0.0

Oct.

Nov

Jan. Feb.

March April

May June

Grarh II. Picea canadensis (leaves). 
TABLE II. Populus tremuloides.

\begin{tabular}{|c|c|c|c|c|c|c|c|c|}
\hline Date. & $\Delta$. & P. & $\Delta_{\ell}$. & $\Delta-\Delta_{e}$. & $\mathrm{C} \times 10^{5}$ & Sucrose \% & Taltose \% & Ghecose \\
\hline Oct. 22 & $I \cdot 247$ & I 4.99 & - & - & - & - & - & - \\
\hline Dec. 7 & $1 \cdot 460$ & $17.5^{6}$ & - & - & - & - & - & - \\
\hline , I6 & $1 \cdot 202$ & $14 \cdot 48$ & - & - & - & - & - & - \\
\hline & $I \cdot 535$ & $18 \cdot 4^{6}$ & $0.08 \mathrm{I}$ & I. 454 & $35^{2}$ & - & - & - \\
\hline Jan. I 8 & $I \cdot 344$ & I6. I7 & 0.083 & $\mathrm{I} \cdot 26 \mathrm{I}$ & 354 & - & - & - \\
\hline Feb. 22 & $I \cdot I 37$ & I 3.68 & 0.120 & $\mathrm{I} \cdot 0 \mathrm{I} 7$ & 518 & 0.20 & $0.9^{8}$ & 0.02 \\
\hline Mar. 23 & $1 \cdot 410$ & $16 \cdot 96$ & 0.078 & $I \cdot 33^{2}$ & 335 & 0.20 & 0.98 & 0.02 \\
\hline May 28 & 0.877 & $10 \cdot 56$ & $0.1 I_{4}$ & 0.763 & 493 & 0.08 & 0.28 & 0.45 \\
\hline
\end{tabular}

1.5 .

$1 \cdot 0$

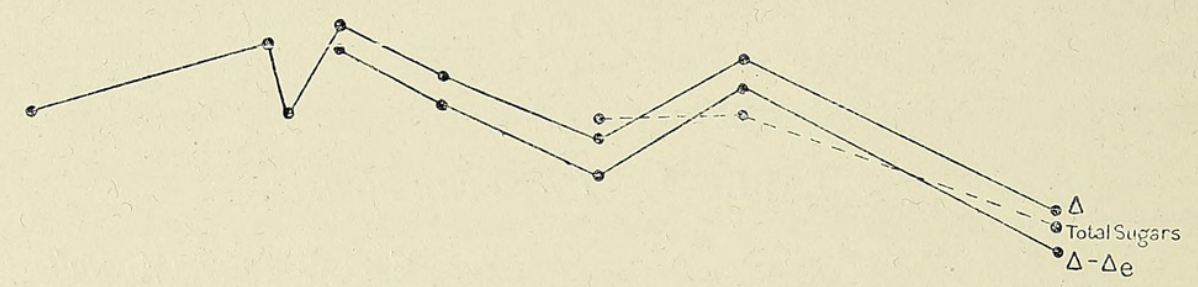

0.5

0.0

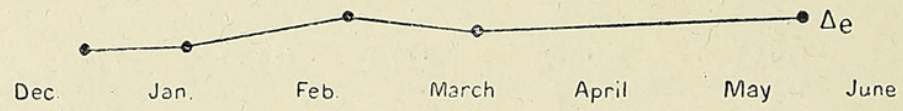

GRAPH III. Populus tremuloides (bark and cortex).

TABLE III. Linnaea borealis.

Date. $\quad \Delta_{0} \quad$ P. $\quad \Delta_{e} . \quad \Delta-\Delta_{e} . \quad \mathrm{C} \times 10^{6}$. Sucrose $\%$. Maltose $\%$. Glucose $\%$.

$\begin{array}{lllllllll}\text { Oct. 24 } & 1.630 & 19.60 & - & - & - & - & - & - \\ \text { Dec. 26 } & 2.080 & 24.99 & 0.342 & 1.738 & 1469 & - & - & - \\ \text { Mar. 21 } & 2.127 & 25.55 & 0.343 & 1.784 & 1473 & 0.20 & 0.91 & 0.00 \\ \text { May 29 } & \text { I.187 } & 14.28 & 0.478 & 0.709 & 2056 & 0.00 & 0.00 & 0.31\end{array}$

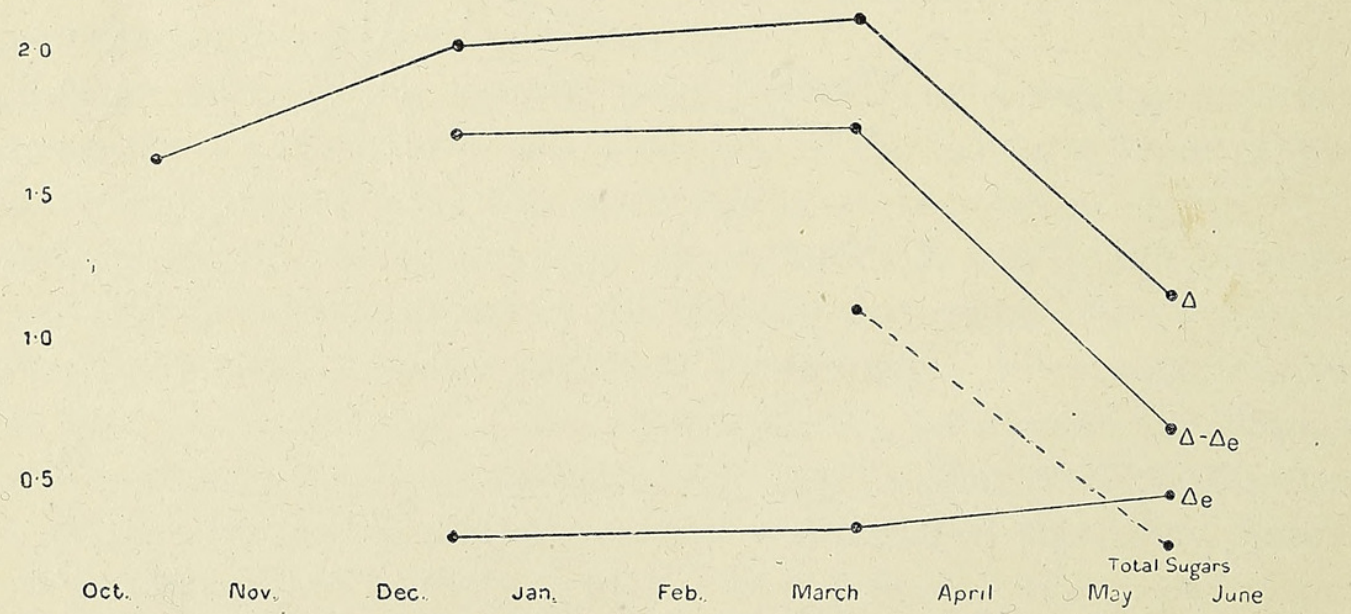

GRAPH IV. Linnaea borealis (leaves). 
TABLE IV. Pyrola rotundifolia.

\begin{tabular}{|c|c|c|c|c|c|c|c|c|}
\hline Date. & $\Delta$. & P. & $\Delta_{e}$. & $\Delta-\Delta_{e}$. & $\mathrm{C} \times 10^{5}$. & Sucrose $\%$ & Maltose \% & Glucose \% \\
\hline Dec. 19 & 2.222 & 26.69 & - & - & - & - & - & - \\
\hline & I. 863 & $22 \cdot 4^{2}$ & 0.223 & 1.640 & $9^{86}$ & - & - & \\
\hline Feb. 8 & $1.99^{2}$ & 23.94 & 0.276 & I.7 6 & I 186 & 0.12 & I. 2 I & 0.00 \\
\hline April II & I. 430 & $17 \cdot 20$ & 0.181 & 1.249 & 780 & 0.00 & $0.1 \mathrm{I}$ & 0.37 \\
\hline June 4 & I. 045 & {$\left[2.5^{8}\right.$} & 0.239 & 0.806 & 1028 & 0.00 & 0.00 & 0.25 \\
\hline
\end{tabular}

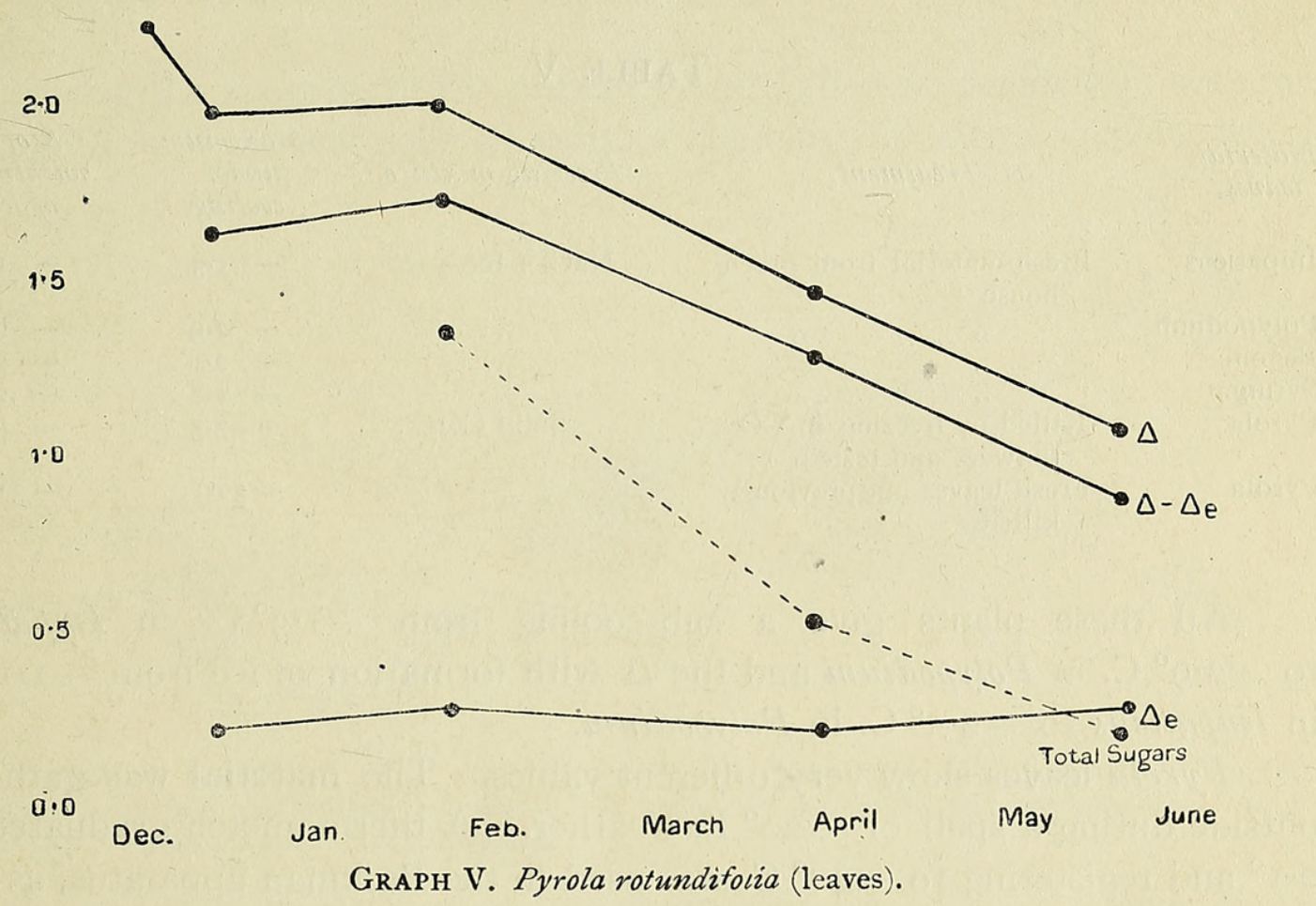

AMOUNT OF UNDER-COOLING AND $\triangle$ OF LEAVES.

Experiments were made to ascertain the temperature at which ice first appears in the leaves of Picea, Linnaea, and Pyrola. Picea leaves were found unsatisfactory to use for this purpose, as they could not be packed tightly round the bulb of the thermometer. Linnaea leaves are too small for successful use, and most of the observations were carried out with the leaves of Pyrola.

Experiments have been carried out by Müller-Thurgau on the freezingpoint of cell sap in situ by either placing the bulb of the thermometer in a succulent tissue such as potato, or wrapping the bulb with the leaves to be tested. This method, while not yielding results comparable in accuracy to those obtained by placing the Beckman thermometer in a solution, is still of considerable value, as it is capable of indicating the amount of undercooling which the minute volume of sap in the cell vacuole is capable of undergoing without the formation of ice. That the amount of sub-cooling in minute volumes, when contact with ice is prevented, may be much greater 
than in comparatively large volumes is indicated by the work of Dufour (4). Direct observations on plant tissues have confirmed this. Thus Müller (2) found the lowest sub-cooling point without freezing of the grape was $-6.8^{\circ}$ to $-7 \cdot 8^{\circ} \mathrm{C}$, while the real freezing-point of the sap was $-3 \cdot \mathrm{I}^{\circ} \mathrm{C}$. Dixon and Joly (10) found ice formation in the tracheides of Taxus began at $-10^{\circ}$ to $-I^{\circ} \mathrm{C}$. In our experiments we first carried out observations on greenhouse plants, and these are recorded in Table $\mathrm{V}$.

\section{TABLE V.}

$\begin{aligned} & \text { Material } \\ & \text { leaves. }\end{aligned}$
Impatiens
Polypodium
Begonia
Syringa
Pyrola
Pyrola

Treatment.

Fresh material from greenhouse

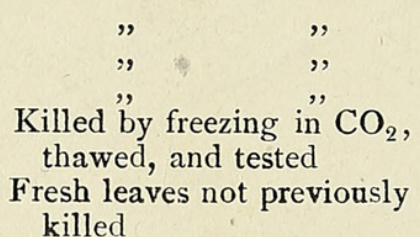

$\begin{array}{ccc}\text { Freezing mixture. } & \begin{array}{c}\text { Maximum } \\ \text { under- } \\ \text { cooling. }\end{array} & \begin{array}{c}\Delta \text { of sap } \\ \text { within cells } \\ \text { of leaf. }\end{array} \\ \begin{array}{ccc}\mathrm{NaCl}+\mathrm{Ice}-\mathrm{IO}^{\circ} & -\mathrm{I} \cdot 3 & -\mathbf{I} \cdot \mathrm{I} \\ , & -2.9 & -2.5 \\ , & -2.8 & -2 \cdot \mathrm{I} \\ \text { Solid } \mathrm{CO}_{2} & -3.8 & -2.5 \\ , & -32 . \mathrm{I} & -3.5\end{array}\end{array}$

All these plants give a sub-cooling from $-\mathrm{I} \cdot 3^{\circ} \mathrm{C}$. in Impatiens to $-2 \cdot 9^{\circ} \mathrm{C}$. in Polypodium and the $\triangle$ with formation of ice from $-\mathrm{I} \cdot \mathrm{I}^{\circ} \mathrm{C}$. in Impatiens to $-2 \cdot 5^{\circ} \mathrm{C}$. in Polypodium:

Pyrola leaves show very different values. The material was gathered outside during a spell of $-20^{\circ} \mathrm{F}$. weather. A thermometer graduated to $\mathrm{O} \cdot \mathrm{I}^{\circ}$ and registering to $-40^{\circ} \mathrm{C}$. was used in the Beckman apparatus, as the amount of under-cooling, was too great to allow the use of the ordinary Beckman thermometer.

The behaviour of the living and dead leaves gave results of some interest. The leaves were killed by freezing in liquid $\mathrm{CO}_{2}$, rapidly thawed, and the amount of under-cooling and $\triangle$ determined. The fresh leaves under-cooled to $-32 \cdot \mathrm{I}^{\circ} \mathrm{C}$., rising to $-3 \mathrm{I} \cdot 65^{\circ} \mathrm{C}$. on the formation of ice in the tissues. The leaves previously killed with liquid $\mathrm{CO}_{2}$, thawed, and tested in the Beckman apparatus using a freezing mixture of solid $\mathrm{CO}_{2}$, under-cooled to $-3.5^{\circ} \mathrm{C}$, rising to $-3 \cdot \mathrm{I}^{\circ} \mathrm{C}$. on the formation of ice in the tissues. Further observations will be carried out next winter by us using the leaves of other northern evergreens. That the condition of the cell contents during periods of low temperature determines the resistance of the tissue to cold is suggested in a paper by one of us in I9I9 (11). Linnaea leaves naturally de-starchified are able to withstand the cold of a northern winter, whilst plants in which the fat has been reconverted into starch are quickly killed on exposure to temperatures of about $-19^{\circ} \mathrm{F} .\left(-28^{\circ} \mathrm{C}\right.$. $)$. 


\section{Condition of Cell Contents at Low Temperatures.}

Pfeffer (12), in describing the work of Mohl, states that the brownishgreen colour of evergreens during winter is due to a partial disorganization of the chloroplastids, accompanied by certain changes in the chlorophyll pigments. In some cases the browning only takes place when the cells are fatally affected, but with the restoration to normal conditions of light the chloroplastids in most conifers recover, turn green, and become functionally active.

During the progress of the present investigation we decided to examine the condition of the leaf cells of some of the material with a view to deter-

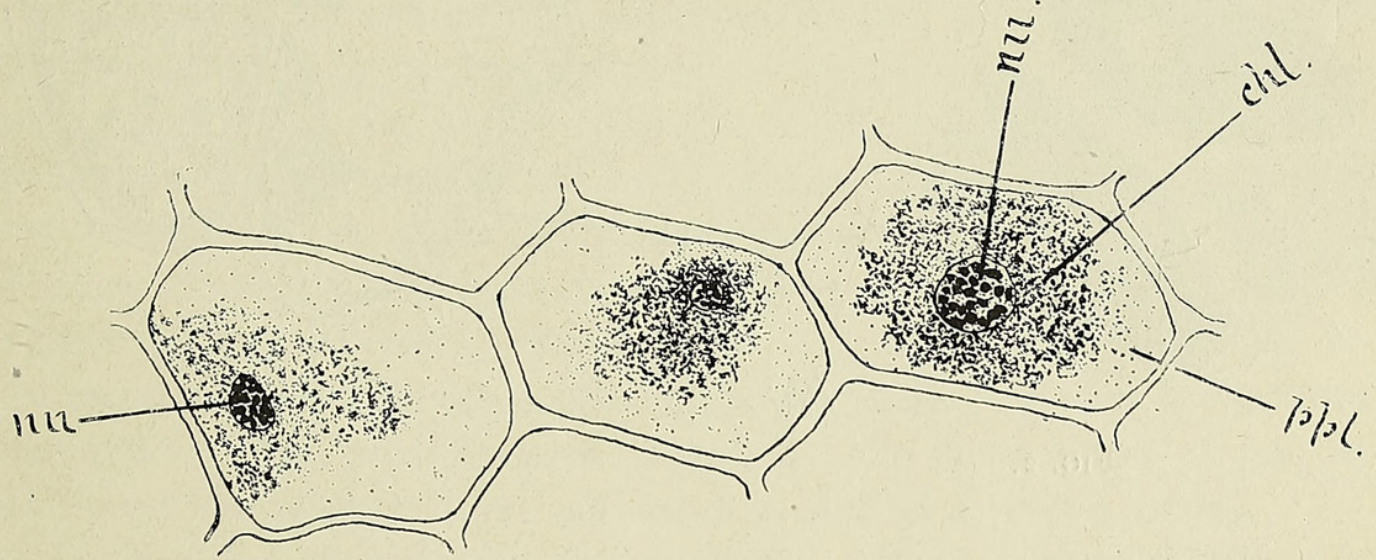

FIG. I. Picea canadensis. Feb. 2I. Mesophyll cells showing 'laking' of the chloroplast. Identity of individual chloroplasts completely lost, nuclei are prominent and very granular. mi. = nucleus, $p$ pl. $=$ protoplasm, chl. $=$ chlorophyll.

mining whether similar features prevailed in this region. Microscopic examination of the mesophyll cells of Picea reveals a distinct localization of the cell contents during winter (Fig. I). In this condition, which prevailed during the coldest weather, the identity of the individual chloroplast was completely lost. The diffuse chlorophyll mass, light yellowish green in colour, was segregated in a relatively small portion of the cell, closely associated with the very granular nucleus. The major portion of the cell was occupied by a large vacuole filled with fat (Fig. 2). All trace of starch disappears early in the autumn.

Leaves were examined frequently during the late winter and early spring, in order that the change to the summer condition might be observed. It was found that the change began quite early and took place within a short time. Cells examined on April 7 differed in several particulars from those of earlier preparations. The chlorophyll mass, though distinctly localized, gave evidence of the formation of distinct chloroplastids. Starch formation had commenced, but was localized in the region of the chloroplasts (Fig. 3). The central vacuole, though smaller, still gave a strong reaction when tested for fat with osmic acid. Three days later the change 
had gone still farther; the chloroplasts, now definite in outline, were arranged at the periphery of the cell. Starch formation around the chloroplast was especially evident at this stage (Fig. 4). Material examined on April I4 revealed the cells in the normal summer condition, the chloroplast being entirely masked by the adherent starch granules (Fig. 5).
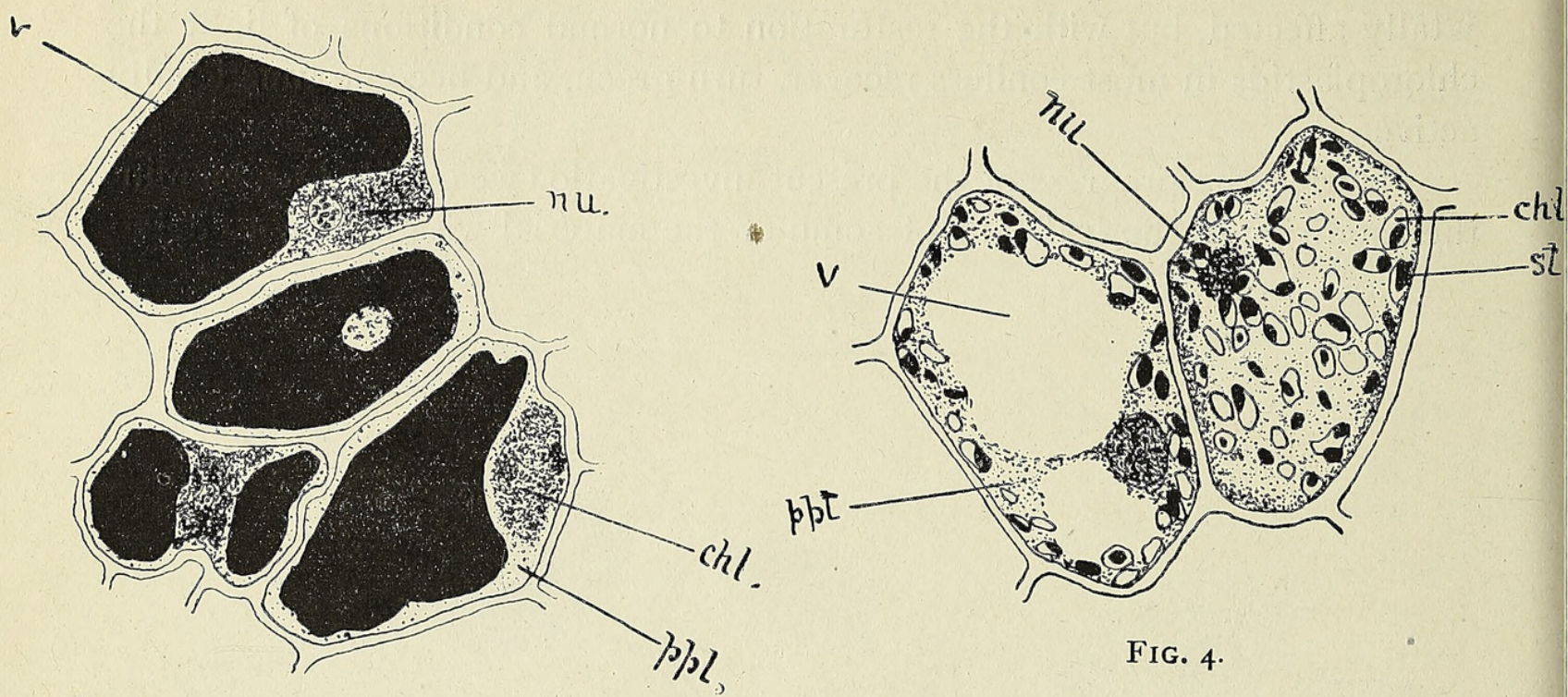

FIG. 2.
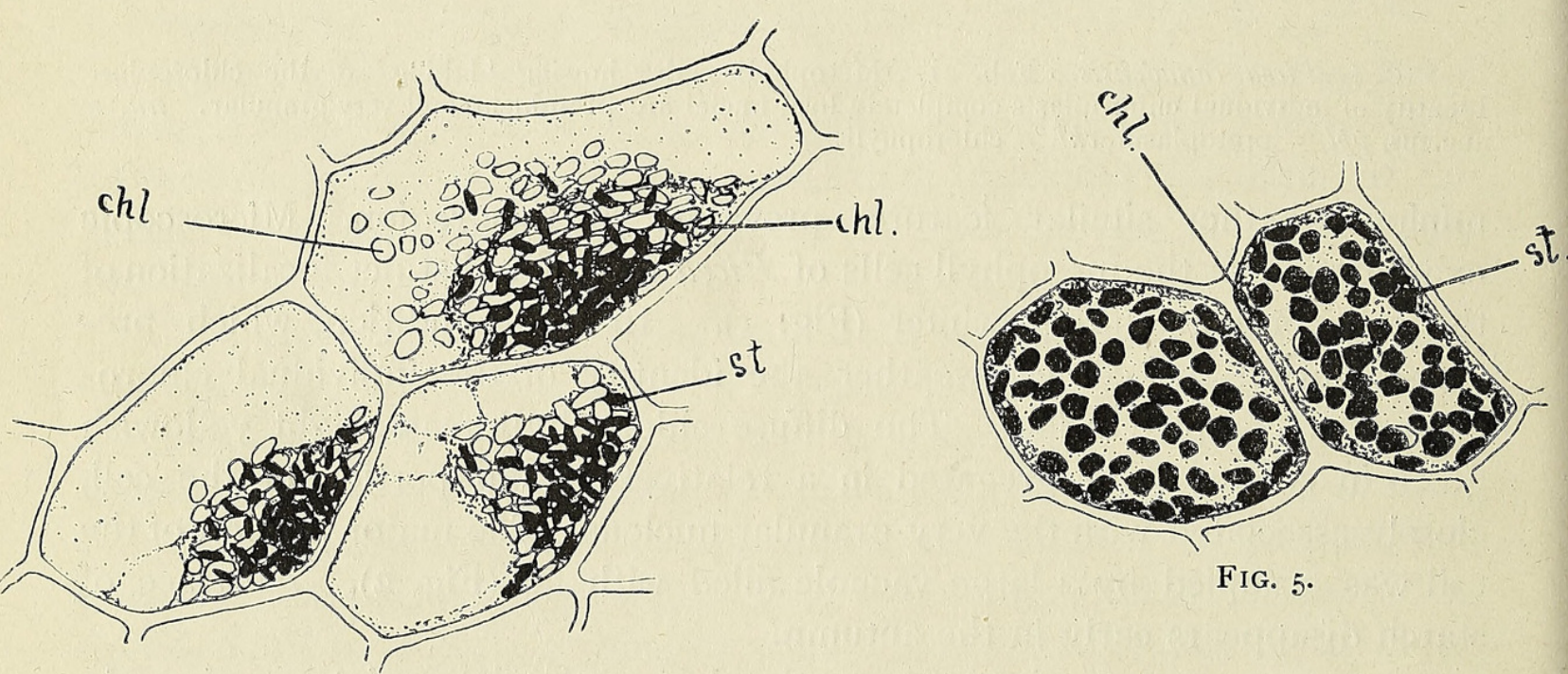

FIG. 3.

Figs. 2-5. Picea canadensis. Fig. 2. Feb. 28. Mesophyll cells after treatment with I \% osmic acid showing vacuoles filled with fats. Fig. 3. Apr. 7. Mesophyll cells treated with iodine solution. Chloroplasts becoming distinct in outline although still localized in distribution; nuclei not visible; starch reaction localized. Fig. 4. Apr. Io. Mesophyll cells in iodine solution. Chloroplasts arranged at periphery of cell; nucleus visible and suspended in central vacuole; starch formation in region of chloroplasts. Fig. 5. Apr. I4. Mesophyll cells treated with iodine solution. Nucleus not visible at this stage. Chloroplasts closely packed round periphery of cell and masked by starch granules. $\quad m u_{0}=$ nucleus, $v .=$ vacuole, $c h l .=$ chlorophyll, $p p l .=$ cytoplasm, $s t_{0}=$ starch. 


\section{Discussion.}

The changes recorded in osmotic pressures cannot be due to peculiarities of individual plants. In the case of Picea, material for each reading was collected from several different trees of approximately the same age, and in Populus the cortical tissue for each pressing was stripped from two or three young saplings. To obtain sufficient sap for a reading of Pyrola leaves from at least 50 or 60 plants had to be used, and more than that number were taken for Linnaea.

In Picea canadensis the osmotic pressure rose during the late autumn months, fluctuated slightly at the end of the year, and then rose steadily to a maximum in late March of 26.9 I atmospheres. By the beginning of June the pressure had fallen to 19.66 atmospheres, but was still higher than the October value of $17 \cdot 13$ atmospheres. The electrolytes show only slight changes throughout the period from December to June, although a decided rise began to be apparent at the end ; approximately 7 weeks after the end of severe frost. The variation of osmotic pressure appears to be due to non-electrolytes. The sugars do not appear to play the chief part in the variation of the non-electrolyte curve $\Delta-\Delta_{e}$, but the rapid increase in the total sugars-especially maltose-at the beginning of starch formation is noteworthy. The possible part played by the metabolism of fats in the variation of the osmotic curve will be discussed in a future paper.

In Populus tremuloides two maxima are observed in the osmotic pressure, but, as in Picea, the pressure falls decidedly as the summer condition is reached. The difference between the maximum and minimum osmotic pressure is only about one-half what it is in the leaves of Picea. Here again, the variation in pressure is due chiefly to non-electrolytes, although the electrolytes show a slight increase from March onwards.

In Linnaea borealis the maximum osmotic pressure is attained about the third week in March and falls rapidly until June, and the electrolyte curve shows a decided rise at the end of the observations. It was impossible to avoid using a number of young leaves for the reading on May 29, and the small osmotic pressure and increase in the electrolytes may be due to this.

Pyrola rotundifolia, unlike the other examples, shows a fairly steady decrease in osmotic pressure from December to June, and the electrolytes remain fairly constant throughout the season. The same fall in the sugar content occurs as the spring is approached, but commences somewhat earlier than in the other plants.

\section{SUMMARY.}

I. Osmotic pressures, electrical conductivities, proportions of electrolytes and non-electrolytes, and the amounts of sucrose, maltose, and glucose have been determined in the leaf tissues of Picea canadensis, Linnaea borealis, Pyrola rotundifolia, and the cortical tissues of Populus tremuloides at intervals from the autumn until the summer. 
2. No certain correlation between the above values and the daily or weekly fluctuations of air temperatures can be recognized without observations extending over more than one season.

3. The maximum osmotic pressure is reached in Picea and Linnaea towards the end of March; in December in the case of Populus, although a second maximum occurs in late March nearly of the same value as the December reading. Pyrola shows a fairly steady decrease from the middle of December till June.

4. The concentration of electrolytes shows very little variation in any of the plants during the whole period of observation. trolytes.

5. The variations in osmotic pressure are due chiefly to the non-elec-

6. The variation of the sugar content closely follows the variation of the osmotic pressure.

7. The sugars show a decided concentration during the winter months.

8. There is a progressive decrease of the sugars from the winter maximum towards the summer.

9. Leaves of Pyrola killed by freezing in liquid $\mathrm{CO}_{2}$ show ice formation at $-3 \cdot \mathrm{I}^{\circ} \mathrm{C}$.

IO. In the living leaves of Pyrola ice formation does not begin until a temperature of $-3 \mathrm{I} \cdot 6^{\circ} \mathrm{C}$. is attained.

I I. During the winter months chlorophyll granules in Picea are completely laked, the chlorophyll being localized in the region of the nucleus.

I2. During the early part of April the chloroplastids assume definite form and starch formation commences.

\section{REFERENCES.}

1. Harris, J. Arthur, and Lawrence, John V.: The Osmotic Concentration of the Tissue

Fluids of Jamaican Montane Rain-Forest Vegetation. Amer. Jour. Bot., I9I 7, vol. iv, p. 5 .

2. MÜLLER : Landw. Jahrb., I886, Bd. xv.

3. Mousson : Annal. d. Physik u. Chemie, $185^{8}$, Bd. cv.

4. Dufour : Annal. d. Physik u. Chemie, I 86 r, Bd. cxiv.

5. Dixon, H. H., and Atkins, W. R. G.: The Osmotic Pressures in Plants. I. Methods of extracting Sap from Plant Organs. Proc. Roy. Dublin Soc.; I9I3, xiii.

6. Benedict, S. R.: A Method for the Estimation of Reducing Sugars. Journ. Biol. Chem., I9I I, vol. ix.

7. HaAs and Hill: The Chemistry of Plant Products. London, igi5.

8. Dixon, H. H., and Atkins, W. R. G.: On the Constituents and Concentration of the Sap in Conducting Tracts, and on the Circulation of Carbohydrates in Plants. Proc. Roy. Dublin Soc., I9I 5 , vol. xiv (N. S.).

9. Harris, W., and Gortner, R. A.: Note on the Calculation of the Osmotic Pressure of Expressed Vegetable Saps from the Depression of the Freezing-point, with a Table for the Values of P. for $\Delta=0.001^{\circ}$ to $\Delta=2.999^{\circ}$. Amer. Jour. Bot., I9I 4, i. 75.

10. Dixon, H. H., and Joly, J.: Annals of Bot., I 895 , vol. ix.

11. Tuttle, Gwynethe M.: Induced Changes in Reserve Materials in Evergreen Herbaceous Leaves. Ann. of Bot., I9I9, vol. xxxiii, pp. $201-10$.

12. Pfeffer, W. : Physiology of Plants, vol. i, p. 335. English Trans. by A. J. Ewart. 


\section{$2 \mathrm{BHL}$ Biodiversity Heritage Library}

Lewis, Francis J. and Tuttle, Gwynethe M. 1920. "Osmotic properties of some plant cells at low temperatures." Annals of botany 34, 405-416. https://doi.org/10.1093/aob/os-34.3.405.

View This Item Online: https://www.biodiversitylibrary.org/item/236972

DOI: https://doi.org/10.1093/aob/os-34.3.405

Permalink: https://www.biodiversitylibrary.org/partpdf/320297

\section{Holding Institution}

Smithsonian Libraries

\section{Sponsored by}

Biodiversity Heritage Library

\section{Copyright \& Reuse}

Copyright Status: Not in copyright. The BHL knows of no copyright restrictions on this item.

This document was created from content at the Biodiversity Heritage Library, the world's largest open access digital library for biodiversity literature and archives. Visit BHL at https://www.biodiversitylibrary.org. 